\title{
Verbal and Visual Communication in the Movie The Hunger Games
}

\author{
Ayu Putu Fridayanti \\ English Department, Faculty of Arts, Udayana University \\ [ayuputufridayanti@gmail.com]
}

\begin{abstract}
Communication can be made by using two kinds of mode; they are verbal and visual communication modes. Nowadays, people tend to focus on the verbal communication and ignore the visual communication itself, even though they have the same important part of communication by using language. This study entitled "Verbal and Visual Communication in the Movie The Hunger Games" is trying to reveal and find out the sentence forms of the characters'verbal utterances, the visual signs of the scene among the characters and the relationship between those communications. In the study, The Hunger Games movie is used as the data source. It tells about a death game that was held by a capitol city which was inhabited by people of the upper class and the people of the lower class who live in the districts as the tribute of the game. The method used to analyze the movie is Qualitative method. The main theory used is proposed by Dyer (1986) with his Verbal and Visual Communication theory and helped by using a theory from Timothy Shopen (2007) describing the types of sentence in form of verbal utterance. Based on the analysis, all of the sentence types as the verbal communication analysis and almost all of the visual sign elements in the movie were found, except for the national and racial element in appearance category. The verbal and visual communications represented in the movie supports each other to convey the meaning. It shows the differences between two different social classes; they are upper and lower classes. How the characters of the upper class speak, act, and look, tend to be more polite, prestigious, classy, colorful, and more educated than the characters of the lower class. It shows the relationship of visual and verbal communication itself.
\end{abstract}

Keywords: visual, verbal, social class.

\begin{abstract}
Abstrak
Komunikasi dapat dilakukan dengan menggunakan dua jenis mode, yaitu mode komunikasi verbal dan visual. Dewasa ini, masyarakat cendrung fokus pada komunikasi verbal dan mengabaikan komunikasi visual itu sendiri, kendati demikian mereka memiliki bagian yang sama penting dalam berkomunikasi dengan menggunakan bahasa. Penelitian yang berjudul Verbal and Visual Communication in the Movie the Hunger Games ini mencoba untuk mengungkapkan dan menemukan bentuk-bentuk kalimat dari ucapan verbal karakter, tandatanda visual di setiap adegan yang terjadi antar karakter, serta hubungan antara komunikasi verbal dan visual tersebut. Penelitian ini menggunakan The Hunger Games sebagai sumber data dimana film ini menceritakan tentang permainan kematian yang diadakan oleh Ibu Kota mereka, tempat yang dihuni masyarakat kelas atas dan masyarakat kelas bawah yang tinggal di distrik sebagai pemain dalam permainan tersebut. Metode yang digunakan dalam menganalisa data adalah Kualitatif. Teori yang digunakan dalam penelitian ini adalah teori verbal dan visual yang diusulkan oleh Dyer (1986) dan dibantu dengan menggunakan teori dari Timothy Shopen (2007) yang mendeskripsikan tentang tipe-tipe kalimat dalam bentuk ucapan verbal. Berdasarkan pada analisis yang telah dilakukan, seluruh tipe-tipe kalimat sebagai analisis komunikasi verbal dan hampir semua tanda-tanda elemen visual dalam film ditemukan, kecuali
\end{abstract}


untuk elemen nasional dan ras di kategori penampilan. Komunikasi verbal dan visual yang ditunjukkan dalam film tersebut saling mendukung satu sama lain dalam menyampaikan arti. Hal itu menunjukkan perbedaan-perbedaan antara dua kelas sosial yang berbeda, yaitu kelas atas dan bawah. Cara berbicara, bertindak, dan penampilan dari karakter kelas atas cendrung lebih bermartabat, berkelas, berwarna dan lebih berpendidikan daripada karakter kelas bawah. Hal itu menunjukkan hubungan komunikasi verbal dan visual itu sendiri.

Kata kunci: visual, verbal, kelas sosial.

\section{Background of the Study}

Verbal and visual communications are in the same field of semantics, but they have some differences. Verbal communication is a language that uses words to express an idea. The opposite of verbal communication is visual communication. It is one of the most important ways that people use to communicate and share information. It is the transmission of information and ideas using symbols and imagery.

Actually, verbal and visual communications have the same degree of importance . But nowadays, people are more confident with the verbal communication only. They tend to ignore the visual communication besides the verbal itself. It can be seen from the increasing of fraud in society every year. Fraud is an act of deception and a series of lies both spoken and written with a view to self-benefit. By this research, it is hoped that people can be more aware and pay more attention to those two kinds of communication, in order to decrease the number of fraud in society.

Verbal and visual communication can be seen from many aspects of our daily life, such as a movie. Movie is a thing that completes both of those communications. It covers motion pictures and also embodies, communicates, and suggests meaning through language. It is an easier thing to use in order to understand the meaning of verbal and visual communication. That is why movie was chosen as the data source.
In this research, a movie entitled "The Hunger Games" published in 2012 was chosen. In the movie, the contrast between two different social classes is shown. The way they speak, act, and look are also different but support each other. These contrast differences make this movie an interesting data to be discussed.

\section{Problem of the Study}

a) What types of sentence form are used by the characters of the movie in their verbal utterance?

b) What types of visual communication are shown by the characters in the movie?

c) How are the relationships between the verbal and visual communication shown by the characters in the movie?

\section{Aims of the Study}

a) To find out the types of sentence form used by the characters of the movie in their verbal utterance.

b) To describe the visual signs of the characters in the movie.

c) To analyze the relationships between verbal and visual communication shown in the movie.

\section{Research Method}

A research method deals with the methods used in analyzing this study. There are four aspects discussed in this research method section: data source, 
method and technique of collecting the data, method and technique of analyzing the data, and method and technique of presenting analysis.

\subsection{Data Source}

The data of this study were directly taken from the movie The Hunger Games which was adapted from a novel by Suzanne Collins with the same title and was produced as a movie in 2012 by Nina Jacobson as the producer. The movie was chosen as the data because the contrast behavior and appearance between the wealthy and poor citizen in the movie that make it more interesting to discuss.

\subsection{Method and Technique of Collecting Data}

The method used for collecting the data was Documentation Method. In collecting the data, there are four steps used. First, downloading the movie; second, watching the movie; third, capturing the pictures of the scenes chosen; fourth, noting the sentence form of verbal utterances used by the characters in the movie; after that, putting the classification of the visual communication. Only three scenes were chosen because those scenes show the differences of speak, act, and look from two social classes, the upper class and lower class.

\subsection{Method and Technique of Analyzing Data}

The method used for analyzing the data is the Qualitative Method. The procedures of the analysis were done as the first was analyzing and describing the sentence form of the verbal utterance by the characters using the theory proposed by Timothy Shopen (2007) in her book entitled "Language Typology and Syntactic Description". Second, analyzing and describing the classification of visual signs shown in the movie using visual analysis based on the theory proposed by Dyer (1986). Third was analyzing the relationship of the verbal utterance by the characters correlated with the visual signs supported the verbal communication.

\subsection{Method and Technique of Presenting Analysis}

In presenting the analysis, the study uses descriptive method. In answering the first question, the result of the verbal utterance analysis is presented in form of paragraph and also table as the conclusion. In answering the second question, a classification type of the visual communication based on Dyer theory is given and presented in form of table. For the third problem, the data are presented in form of paragraph and give some explanation about verbal and visual communication in the picture taken completely with the utterance of the movie before, and tell the reader whether those elements are in line or not.

\section{Result and Discussion}

The results and discussions of this study are divided into the characters of the movie, the synopsis of the movie, and also the analysis of verbal and visual of the scene chosen in the movie.

\subsection{The Characters of the Movie}

This study focuses on five characters because those characters show interesting facts about the verbal and visual communication by the upper and lower classes' society in the movie. The name of the actors and actresses who take a role of the characters are given as follows:

Cast:

Jennifer Lawrence as Katniss Everdeen

Liam Hemsworth as Gale Hawthrone

Willow Shields as Primrose Everdeen

Wes Bentley as Seneca Crane 
Elizabeth Banks as Effie Trinket

\subsection{The Synopsis of the Hunger Games}

The movie tells about the death game called The Hunger Games who announce across the nation as the entertainment and also to reinforce the government's total power. A man and a woman are chosen as the tribute of their district for that death game. Someone who wins the tournament was given food and the ease of life for her or his family and her or his district.

\subsection{The Analysis of Verbal and Visual in The Movie Hunger Games}

The analysis of verbal and visual communication was limited to three scenes. Those scenes were chosen because they show contrast differences between the upper and lower classes in the way they speak, act, and look of their verbal and visual communications.

\subsubsection{Verbal Communication Analysis}

Based on Timothy (2007) book entitled "Language Typology and Syntactic Description", there are 4 types of sentences and all of those sentences were found in the characters' verbal utterances of the movie, the examples are presented below:

\section{a) Declarative}

\section{"I believe we have a volunteer." ( $5^{\text {th }}$ utterance of scene two) "Katniss Everdeen. District 12." ( $1^{\text {st }}$ utterance of scene three)}

The utterances above have declarative forms, shown by their function to state about the volunteer and the character who states her name and the district where she comes from. It is also supported by the period as the punctuation at the end of the sentence.

\section{b) Interrogative}

"What're you gonna do with that when you kill it?" ( $1^{\text {st }}$ utterance of scene one)

"What's your name?"

( $8^{\text {th }}$ utterance of scene two)

The utterances above have an interrogative form. The first utterance asks about the purpose of doing something and the second one asks about the information of someone. It is supported by the question marks as the punctuation at the end of the sentences.

\section{c) Imperative}

"Well, come on up!" (Second sentence of the $3^{\text {rd }}$ utterance of scene two)

"Go find Mom! Prim, Go find

Mom!"'(Second sentence of the $6^{\text {th }}$ utterance of scene two)

The utterances above have an imperative form. Those utterances have a function to give a command to someone. It is supported by the act between the characters who said it and the punctuation at the end of the sentences.

\section{d) Exclamatory}

$$
\begin{gathered}
\text { "Primrose Everdeen!" } \\
\left(2^{\text {nd }}\right. \text { utterance of scene two) } \\
\text { "Damn you, Gale!" } \\
\left(2^{\text {nd }}\right. \text { utterance of scene one) }
\end{gathered}
$$

The utterances above have an exclamatory form. Those utterances convey emotion from the characters who said it. The exclamation point at the end of the sentences functions to give a tension and a strong feeling when the characters said it. 


\subsubsection{Visual Communication Analysis}

The visual analysis was done by using the theory proposed by Dyer (1986) in his book entitled "Advertising as Communication". There are five categories in visual communication, which are divided into some elements. Appearance category is divided into age, gender, national and racial, hair, body and size, and looks, manner category is divided into expression, eye contact, pose, and clothes, activity category is divided into touch, body movement, and positional communication, props and setting category, and analyzing photographs is divided into focus and depth of vision, close-ups, lightning and color, cropping, camera angle, and special effects or montage.

\section{a) Appearance}

Based on the analysis that has been done, the characters Katniss and Gale were teenagers and the character Effie and Crane were adults which were the oldest characters in the data. Primrose was the youngest one. Katniss, Gale, and Primrose wore simple clothes with a pale color. They did not use striking make up on their face, especially for Katniss and Primrose. In contrast with Crane and Effie who look more classy and prestigious with their colorful outfit, accessories, and striking make up applied on their face, especially for Trinket.

Katniss was a thin and tall woman with long curly brown hair. Primrose was a thin and short girl with long straight blonde hair. Gale was a well-built and tall man with short curly brown hair. Crane was a thin and tall man with short straight black hair. Effie was a thin woman. Her hair cannot be detected due to the wig that she always changed based on the color of her outfit.

\section{b) Manner}

Manner indicates behavior of emotion at any time and it is manifested in four elements of manner, they are expression, eye contact, pose, and clothes.

Expression of annoyance and disappointment were shown by Katniss at scene one; it was because she failed to catch her prey because of Gale. In contrast, Gale showed an innocent expression like he did not care about what he caused. On scene two, Katniss and Prim tended to show a sad expression because Prim was chosen as the tribute of the death game and Katniss could not believe it. In contrast, Effie as a representative of the city showed a happy expression along this scene. At scene three, anger expression was shown by Katniss because her effort was ignored by the gamekeeper, especially Crane, and Crane showed a shock expression when Katniss pointed her arrow at the gamekeepers.

Beside expression, there was also eye contact element. Eye contact happened many times in the data. It happened among the characters. From the eye contact, the feeling and the relationship from one character can be known to the others.

After eye contact, there was also pose. Pose can be divided into two kinds of poses; active pose and passive pose. In scene one, the characters tended to use an active pose because it told about hunting a deer in the forest. In scene two, Katniss and Prim tended to act with active poses rather than passive poses. Meanwhile, Trinket tended to use a passive pose because she always stood up on the stage along the scene.

Last was the clothes of the characters. Katniss, Gale, and Primrose always wore simple and casual clothes without any accessories. The color of their clothes 
was also pale, without any bright color. It was different from the clothes which were worn by Effie and Crane who came from a rich city. They tended to wear colorful, classy, and prestigious clothes with a striking make up and a unique hair style. Crane also made a unique design on his beard and moustache.

\section{c) Activity}

The observation of activity in the scene presents three elements such as touch, body movement, and personal communication.

Touching can happen among the characters or between the character and an object around the character itself. From this element, it can be felt a feeling among the characters. In scene two, the touching between Katniss and her sister showed a deep feeling. It seemed like they could not be separated. Katniss touched her sister strongly to convince her sister, Prim, to go away from that place because she was already changed by Katniss. The touching between the characters and the inanimate objects also happened in scene three. It was between Katniss and her arrow and also between Crane and his glass.

Beside touching, there were also body movement who showed all acts that had been done by the characters. Running, hugging, walking, hiding, and shooting were identified as the body movement of the movie.

Last is positional communication. From this element, the relationship between the characters can be shown. Gale and Katniss from scene one have a close relationship as a friend. Kaniss and Prim had a close and priceless relationship. It seemed like they could not be separated from each other. In contrast, Katniss and Effie looked like a stranger that had never met before. Katniss tended to ignore what Effie said to her and she did not give a respect to Effie as the older. It also happened to Crane from Katniss.

\section{d) Props and Setting}

Some props occurred so frequently in visual communication that they had gained a conventionalized or symbolic value. In scene one, an arrow and its bow brought by Katniss was a prop that symbolized a brave and strong woman. In scene two, a mic was the prop. The mic always stood on the stage. The use of mic there could show that was an event that were attended by many people. In scene three, the arrows and their bow, the glass and other classy bright color things around the gamekeeper's place were used as props in this scene. The arrows and their bows used by Katniss showed her strength and her ability. The glass used by Crane showed that he came from the upper class and full of riches. It was also shown and supported by all of classy and the bright color things in the gamekeeper place, besides the glass, like the purple sofa, the foods, etc.

The setting element can be divided into two settings, indoor and outdoor setting. Scene one and two showed an outdoor setting. Scene one happened in the forest and scene two happened in a big hall of District twelve. Scene three happened in indoor setting. It is held in a big room with very tight security.

\section{e) Analyzing Photographs}

In analyzing photographs category, there are first, focus and depth of vision. It happened many times in the movie. In scene one, it happened when Katniss was ready to shoot her prey with her arrow. The face of Katniss looked clear, meanwhile her surrounding was presented in fuzzy description. It also happened in scene two when the name of 
Katniss's sister, Prim, was called the tribute of District Twelve. In scene three, it happened twice. First was when Katniss looked at the gamekeeper's side and introduced herself and when Katniss was ready to shoot the target board where Katniss looked in fuzzy description.

Besides, there was also close-ups element. In scene one, the close up pictures could be seen when Katniss and Gale were startled by the arrival of a large aircraft above them and also when Katniss shot the deer but failed. In scene two, the shock and fear expression of Katniss and Prim were presented in close up way. In scene three, the face of Katniss was presented again in close up way when Katniss showed her curious and annoyed expression in feeling unnoticed. The shock face of Crane at the end of the scene was also shown in close up way.

Next is lightning and color of the movie influence the atmosphere of the story. The atmosphere of tranquility and peace appeared with a combination of green and chocolate color which was described by the color of the wood view and the color of the clothes and the arrows as things used by the characters in scene one. The lightning that appeared from the aircraft changed the attention and the atmosphere of the scene into being tense. In scene two, atmospheres which were shown in this scene was a distress and a poor society; it was supported by the pale color of clothes of the people of District twelve. But this atmosphere as if broken by Trinket with her bright purple shades that showed that she came from a rich family and not from District twelve. The lightning of this scene was only a natural light from the Sun. In scene three, the atmosphere of tension appeared with dark color that was supported with the color of the wall and the properties there. The atmosphere of luxury and happiness appeared with the bright color of the gamekeeper's side.

In cropping elements, all of the cropping happened for the hand of the characters, such as the hand of Katniss when she was ready to shoot her prey in scene one, the hand of Trinket who chose the name of the tribute in scene two, and the hand of Katniss who was ready to shoot the target board in scene three. For the camera angle element, there were three camera angles happening in scene one; they are front angle, back angle, and under angle. In scene two, there were front angle, back angle, and side angle. In scene three, there were five camera angles happening, they are front angle, back angle, above angle, below angle, and side angle.

For the special effect or montage in scene one was the song sung without music in a slow voice when Katniss hunted the deer and also thunderous voice and the falling leaves when the aircraft was coming. In scene two, there was a heavy bass sound and the music that began just after Katniss stared ahead with a blank stare, supported by a gust of wind that played her hair softly. In scene three, there was the sound of arrow who hit its target and a music who appeared when Katniss did her second chance that added the tension of this scene.

\subsubsection{The Relationship between Verbal and Visual Communication Analysis}

Visual and verbal signs are two things who take the important part of communication. In scene one, by looking at the characters' appearance, manner especially their eye, activity especially from their positional communication and touch, and from the way they speak with each other, using the informal utterances such as "Damn you, Gale! It's not funny." Damn is an improper word to say to someone, but Gale does not get angry when Katniss says that word to him, they 
also talk without any hesitation, indicating that they were close friends.

In scene two, Trinket's style of clothes and make up are also supported with the way they speak and the words where she prefer to use an idiom indicating that she is an educated person who comes from the upper class; it is certainly inversely proportional to Katniss and Prim, especially Katniss who is less graceful.

In scene three, From Katniss's expressions and eye contacts, it could be seen that Katniss did not really like the gamekeepers. Unappreciated feelings of disrespect could be seen from Katniss' eyes as she thanked the gamekeepers. The thank you words spoken by Katniss were a sarcasm, she gave a tension to the words "for your consideration" as a hard satire against the attitude of the gamekeepers. The clothes used by the gamekeepers and Katniss were also different. The gamekeeper showed a more luxurious appearance, colorful, complete with a striking hairstyle and beard, But Katniss wore a simpler outfit that shows her district. Their different social classes are shown.

\section{Conclusion}

Based on the analysis and discussion above, the following point can be presented as the conclusions are as follows:

The analysis of verbal communication has classified the types of sentence form in the characters' verbal utterances, and all of those types can be found in this study. The analysis of visual communication classified and described the 21 elements of five categories in visual analysis theory. Almost all of those elements could be found, except for the national and racial element in appearance category that could not be found because the movie did not mention the specific nation of country. For the relationship of verbal and visual communications in the movie, it was found that The ways the characters from the upper class spoke, acted, and looked, tended to be more prestigious, classy, with a colorful outfit, and more educated than the characters of the lower class who tended to be what they were with plain appearance and the way they spoke was less educated using rough language.

\section{References}

Braudy, Leo \& Marshall Cohen. 2009. Film Theory and Criticism Introductory Readings. New York: Oxford University Press.

Chandler, Daniel. 2001. Semiotics the Basics. Second Edition. London: Routledge.

Cobley, Paul. 2001. The Routledge Companion to Semiotics and Linguistics. London: Routledge (Taylor \& Francis Group).

Dyer, Gillian. 1982. Advertising as Communication. London: Methuen \& Co. Ltd

Jacobson,Nina. 2012. The Hunger Games Movie. USA: Lionsgate

Shopen, Timothy.2007.Language Typology and Syntactic Description. New York:Cambridge University Press 